
\title{
Resesarch Sulure \\ Changes in Surface Urban Heat Island Effect with the Development of New Towns
}

\author{
Kyungil Lee \\ Korea University \\ Yoonji Kim \\ Korea University \\ Hyun Chan Sung \\ Korea University \\ Seung-Hee Kim \\ Chapman University \\ Seong Woo Jeon ( $\square$ eepps_korea@korea.ac.kr) \\ Korea University
}

\section{Research Article}

Keywords: thermal research, climate, urban heat islands, Pangyo, urbanisation

Posted Date: May 13th, 2021

DOl: https://doi.org/10.21203/rs.3.rs-515349/v1

License: (c) (1) This work is licensed under a Creative Commons Attribution 4.0 International License. Read Full License 
1 Changes in surface urban heat island effect with the development of new towns

2 Kyungil Lee ${ }^{1}$, Yoonji Kim ${ }^{1}$, Hyun Chan Sung ${ }^{1}$, Seung Hee Kim² ${ }^{2}$, and Seong Woo Jeon ${ }^{1 *}$

3

${ }^{1}$ Division of Environmental Science \& Ecological Engineering, Korea University, 02841145 Anam-ro, Seongbuk-gu, Seoul,

$4 \quad 02841$

$5 \quad{ }^{2}$ Center of Excellence in Earth Systems Modeling and Observations, Chapman University, Orange, CA 92866, USA.

6 Abstract

7 A new town is a planned and built within a relatively short period compared to existing cities. It is suitable for climate and thermal research, particularly formulating urban planning strategies to analyse problems such as urban heat islands (UHIs). Herein, a comprehensive approach was demonstrated for determining changes in surface UHI (SUHI) distribution during 1989-2048 in two new towns with different urban planning. A significant increase in built-up areas was observed from $1989(<5 \%)$ to 2018 (> 40\%) in both new towns. However, the areas where SUHIs occurred before and after development increased further (approximately 12.25\%) in Bundang new town where the green area ratio was lower and the building density was higher. However, in terms of SUHI intensification, the building structure of Pangyo new town, which has a lower floor area ratio, was analysed to be more suitable. Moreover, without effective mitigation, the built-up area in each new town is estimated to increase to approximately $60 \%$, and the SUHI intensity in most areas to increase by $4{ }^{\circ} \mathrm{C}$ in 2048 . Thus, these results combined with architectural assessment models can improve the understanding of thermal environmental impacts of urbanisation and help mitigate urban thermal hazards.

Global population growth and urban expansion primarily cause land use and land cover (LULC) changes and increases in built-up area. In 2018, approximately 55.3\% of the world's population resided in cities, among which $60 \%$ will reside in cities with approximately 0.5 million inhabitants by $2030^{1}$. Rapidly increasing economic development accelerates these changes, particularly in fast-growing urban areas, hindering sustainable development ${ }^{2}$. LULC changes induced by human activities lead to different local climates than in surrounding areas. This effect, termed as urban heat island (UHI), occurs worldwide ${ }^{3,4}$. UHIs primarily occur due to increased solar radiation absorption and trapping in new surface materials of various infrastructure ${ }^{5,6}$. The magnitude and extent of UHIs are highly positively correlated with urban area and population size in cities; 
thus, UHIs are significantly affected by urban expansion ${ }^{7}$. UHIs can be divided into two types: meteorological UHI, an increase in local air temperature ${ }^{8}$, and surface urban heat island (SUHI), an increase in urban skin temperature ${ }^{9}$. SUHI is particularly evident in spatial variations of upwelling thermal radiance caused by LULC changes and is commonly influenced by the surrounding sub-urban environment ${ }^{8,9}$.

A new town, also called planned city, is built in a short period within a pre-determined boundary for specific purposes. Since the mid-to-late twentieth century, new towns have been constructed worldwide, contributing to population growth and inflation in large cities ${ }^{10,11}$. New towns facilitate climate and thermal research through formulation of urban planning strategies to analyse problems, such as UHIs, and by providing information on the urban temporal temperature variation mechanism ${ }^{12}$. Comparison of UHI changes in new towns have not yet been conducted. Carrying out comparative studies on climate effects of urbanisation under different urban planning conditions is particularly difficult because of different urban environments, economic situations, and climates, as well as inconsistent data.

Since 1990, 14 new towns have been repopulated or built in sub-urban areas in South Korea to manage population, transportation, and environmental concerns in several large cities. Urban planning in the firstgeneration new towns, providing indiscriminate housing, was not systematic and resulted in negative impacts, such as unplanned urban expansion, environmental degradation, and low greenspace ratio in housing complexes. The second-generation new towns were developed through systematic and environmentally friendly urban planning, such as low-density urbanisation and expansion of green areas (Table 1). However, in both cases, an increase in UHI is estimated because of a rapid infrastructural development and vegetation loss. Moreover, the UHI phenomenon may intensify with further urban expansion.

Herein, expansion and intensification of UHI due to new town development was empirically analysed using satellite data in two different-generation new towns in South Korea (Fig. 1). The SUHI intensity of each new town is the difference between the temperatures of built-up and surrounding areas within the boundary ${ }^{4,13-}$ LULC changes in the two new towns. Notably, urban planning influenced the change patterns in the expansion and intensification of UHIs, despite urban expansion. Furthermore, the future SUHI intensities in new towns may significantly increase with changes in structural characteristics owing to renovation and additional urban expansion.

\section{Results}


classifications, the kappa coefficient in LULC classification areas for all the three years were greater than 0.8 , verifying that these classifications were significant predictors of future LULC and SUHI distribution. LULC analysis showed that the extent and proportion of LULC types varied temporally, and significant transformations were observed between 1989 and 2018. The accumulation of built-up areas in the two new towns has been significantly increased during each development period (Fig. 2b and Fig. 3b). However, forest and agricultural areas had significantly declined. In 1989, most of the LULCs in Bundang new town and Pangyo new town were forest and agricultural areas, accounting for approximately $85 \%$ of the total area, while built-up areas accounted for less than 5\%. After that, the highest built-up growth occurred in Bundang new town between 1989 and 2000, when the development phase of Bundang new town was over. The built-up areas increased from $1.47 \mathrm{~km}^{2}$ (4.39\%) to $14.09 \mathrm{~km}^{2}$ (42.13\%); however, agricultural areas significantly decreased from $13.90 \mathrm{~km}^{2}(41.55 \%)$ to $2.99 \mathrm{~km}^{2}(8.93 \%)$, and forests also considerably decreased from $44.19 \%$ to $33.88 \%$. In addition, open spaces increased from $0.46 \%$ to $5.68 \%$, which was due to the development of the new town, or because it was an area under development at that time (Fig. 2a). In Pangyo new town, very little change had occurred because new town development planning was not yet established. In the case of built-up areas, the proportion increased from $3.23 \%$ to $16.73 \%$, which was confirmed by the construction of the main road within the boundary and unplanned and fragmented development (Fig. 3a). This also evidently increased the percentage of open spaces in this process.

In 2018, when the development of Pangyo new town was completed, the proportion of built-up areas in this new town considerably increased from $16.73 \%$ to $40.81 \%$. Forest areas decreased from $8.17 \mathrm{~km}^{2}(46.38 \%)$ to $7.20 \mathrm{~km}^{2}(40.84 \%)$ and the remaining agricultural areas decreased to $1.96 \%$, resulting in almost complete urbanisation. In the case of Bundang new town, urban expansion occurred through additional urban development and partial renovation between 2000 and 2018. The proportion of built-up areas increased by $7 \%$ but agricultural areas decreased by $1.71 \%\left(0.57 \mathrm{~km}^{2}\right)$; indicating almost complete urbanisation. Open spaces that existed in both new towns in 2000 were also mostly urbanised in 2018. Due to the low resolution of images, the grass in the built-up areas could not be classified, but the proportion of grass was higher in Pangyo new town than in Bundang new town as recorded during urban planning. The actual ratio between the two new towns would be different. In the case of water bodies, there was no significant change in the areas between 1989 and 2018, but fluctuations due to spectroscopic differences were observed. 

intensity areas in both the new towns had increased with urban expansion (Fig. 2d and Fig. 3d). In 1989, there were no areas in both Bundang and Pangyo new towns with a SUHI intensity of six or higher. Most of the areas with evident SUHI phenomenon were agricultural areas and partially urbanised areas. Land surface temperature (LST) is sensitive to vegetation mass, and in Korea, May is an early growing season in agricultural areas that contain less vegetation mass compared to the surrounding fores $\mathrm{t}^{16}$. This difference in vegetation mass led to a high temperature distribution in agricultural areas in both new towns. In 2000, the area with SUHI phenomenon increased by approximately $30 \%$ after the development of Bundang new town. The areas with SUHI occurrence in the range of $2{ }^{\circ} \mathrm{C}-4{ }^{\circ} \mathrm{C}$ significantly increased from $3.4 \mathrm{~km}^{2}$ (10.18\%) to $10.82 \mathrm{~km}^{2}(32.34 \%)$, and those with more than $4{ }^{\circ} \mathrm{C}$, which were few in 1989 , increased to approximately $3.03 \mathrm{~km}^{2}(9 \%)$ of the total area. In the case of Pangyo new town, the areas with the SUHI phenomenon increased by approximately $6.5 \%$, and most of these were distributed across the built main road and surrounding areas. The area with SUHI occurrence in the range $2{ }^{\circ} \mathrm{C}-4{ }^{\circ} \mathrm{C}$ increased from $1.77 \mathrm{~km}^{2}(10.06 \%)$ to $3.23 \mathrm{~km}^{2}(18.33 \%)$, and those with more than $4{ }^{\circ} \mathrm{C}$ were less than $0.324 \mathrm{~km}^{2}$ (2\%) (Fig. 2c). Compared to the developed Bundang new town, Pangyo new town showed a smaller overall increase in the SUHI phenomenon.

In 2018, when the development of Pangyo new town was completed, the areas experiencing the SUHI phenomenon increased by approximately $17 \%$. The areas with SUHI occurrence in the range $2{ }^{\circ} \mathrm{C}-4{ }^{\circ} \mathrm{C}$ increased from $3.23 \mathrm{~km}^{2}(18.33 \%)$ to $4.68 \mathrm{~km}^{2}(26.58 \%)$, and those in the range $4-6{ }^{\circ} \mathrm{C}$ significantly increased from $0.32 \mathrm{~km}^{2}(1.81 \%)$ to $2.51 \mathrm{~km}^{2}(14.23 \%)$. However, few areas were found that had temperatures greater than $6{ }^{\circ} \mathrm{C}$, and none exceeded $8{ }^{\circ} \mathrm{C}$. For Bundang new town, the areas with $\mathrm{SUHI}<2{ }^{\circ} \mathrm{C}$ had decreased, and the areas with higher SUHI intensity had increased overall. The areas with SUHI in the range $4{ }^{\circ} \mathrm{C}-6{ }^{\circ} \mathrm{C}$ increased from $2.76 \mathrm{~km}^{2}(8.25 \%)$ to $3.69 \mathrm{~km}^{2} 11.03 \%$, and those with more than $6{ }^{\circ} \mathrm{C}$ increased to approximately $2 \%$ of the entire new town. This implied that the increase in building density and building renovation through additional development may be the main causes of the intensified SUHI phenomenon in existing cities (Fig. 3c). Buildings are responsible for more than $40 \%$ of the global energy consumption, and structural characteristics are related to the UHI intensity ${ }^{17,18}$. Renovation for outdated buildings, such as extension and new construction, intensify the UHI phenomenon ${ }^{18}$. The increase in total area and intensity of the SUHI phenomenon before and after Pangyo new town development was evidently lower than that of Bundang new town. However, the area with SUHI in the range of $4{ }^{\circ} \mathrm{C}-6{ }^{\circ} \mathrm{C}$ increased higher than that of Bundang new town. This may also be due to 
differences in structural characteristics, floor area ratio, and height of buildings built in new town. The floor area ratio of buildings in Bundang new town is higher than in Pangyo new town.

Building floor ratio means the sum of the gross horizontal area of each floor of a building as measured to the exterior face of the exterior walls of the building. According to Oke et al. $(2017)^{14}$, the facet surface temperature in daytime in urban system is typically ranked as follows: $\mathrm{T}_{\text {roof }}>\mathrm{T}_{\text {walls }}>\mathrm{T}_{\text {floor }}>\mathrm{T}_{\text {surrounding area. }}$. In addition, in canyons formed in the city through high-rise buildings, overshadowing areas are formed to induce surface coolness ${ }^{60}$. As a result, it was found that buildings newly built in Pangyo new town, which have a lower height than Bundang new town and a certain level of building coverage ratio, are more suitable for increasing surface temperature.

Predicted LULC for 2028, 2038, and 2048. The cellular automata (CA)-Markov chain model (MCM) analysis predicted that the proportion of built-up areas would increase by approximately $10 \%$ from $16.44 \mathrm{~km}^{2}$ (49.16\%) to $19.78 \mathrm{~km}^{2}$ (59.12\%) between 2018 and 2048 in Bundang new town (Fig 2a). Moreover, it predicted decreases in forest areas from $35.61 \%$ to $29.9 \%$ and the grass cover from $12.76 \%$ to $10.69 \%$. As new town development in the past primarily occurred through transformation of agricultural areas to built-up areas, it was not predicted that a significant urban expansion would occur through deforestation. In addition, most of the buildings in the housing complex of Bundang new town were completed in 1990, over 25 years ago. Therefore, renovations are planned for most of these old apartment complexes to improve the poor residential environment and meet the latest urban housing requirements. Hence, most urban expansion was predicted to occur through renovation within the existing built-up areas and partial transformation of the forest surrounding the new town. In the case of Pangyo new town, the proportion of urban expansion between 2018 and 2048 was predicted to be higher than that of Bundang new town. According to the CA-MCM prediction, built-up areas would increase by approximately $18.42 \%$ from $40.81 \%$ to $59.23 \%$, the forest areas would decrease from $40.84 \%$ to $32.25 \%$, and the grass cover including golf courses would decrease from $15.34 \%$ to $7.92 \%$ (Fig. 3a). The primary trend observed in the predicted urban expansion was that non-urban areas, such as forest and grass, surrounding the main road were transformed into built-up areas. In contrast with Bundang new town, Pangyo new town is public-transportation-oriented. During the past new town development, the areas surrounding the main road that existed outside the city were underdeveloped. However, if urban expansion occurs in the future, it would be evident primarily in areas with good road proximity. In addition, urban expansion due to the completion of development in the open spaces that were under development in 2018, and further development 
within the city was also predicted. In terms of agricultural area and water, both new towns were predicted to remain almost unchanged from 2018, with little fluctuation.

Predicted SUHI distribution for 2028, 2038, and 2048. CA-MCM predicted the increase in area and intensity of the SUHI phenomenon in both new town and, unlike LULC prediction, a significant change was predicted. In Bundang new town, the areas where the SUHI phenomenon occurs would increase by approximately $5 \%$ between 2018 and 2048. For SUHI intensity distribution, the areas with SUHI $\leq 4{ }^{\circ} \mathrm{C}$ would decrease from $17.12 \mathrm{~km}^{2}(51.16 \%)$ to $11.44 \mathrm{~km}^{2}$ (34.21\%). Simultaneously, the areas with SUHI $>4{ }^{\circ} \mathrm{C}$ was estimated to increase from $4.25 \mathrm{~km}^{2}(12.73 \%)$ to $10.68 \mathrm{~km}^{2}$ (34.71\%), affecting the lower SUHI intensity areas. It is predicted that SUHI intensity would expand and increase from the existing residential area, which may reflect the renovation trend partially occurring between 2000 and 2018. Therefore, development of sustainable renovation guidelines is required such as thermal insulation, replacement of the insulation material, and improving the air tightness of the building envelope through renovation using insulation materials ${ }^{19}$. In addition, the areas with SUHI $>6{ }^{\circ} \mathrm{C}$ are predicted to increase from $0.56 \mathrm{~km}^{2}(1.7 \%)$ to $2.77 \mathrm{~km}^{2}(8.28 \%)$. It has been observed that the higher the LST, the higher the frequency of heat waves at regional scales ${ }^{20}$. In the future, additional thermal environmental policies and energy policies are required for areas where SUHI intensity is expected to increase significantly (Fig. 3a).

In the case of Pangyo new town, the areas where the SUHI phenomenon occurred were predicted to increase by $20 \%$. The affected areas are similar to those predicted to change from forests existing around the main road to built-up areas. For SUHI intensity distribution, the area with $\mathrm{SUHI} \leq 4{ }^{\circ} \mathrm{C}$ would decrease from $7.75 \mathrm{~km}^{2}(43.97 \%)$ to $5.08 \mathrm{~km}^{2}$ (28.83\%). Moreover, the areas with SUHI $>4{ }^{\circ} \mathrm{C}$ would increase from $2.53 \mathrm{~km}^{2}$ (14.34\%) to $8.7 \mathrm{~km}^{2}(49.36 \%)$, and most areas were in the range $4{ }^{\circ} \mathrm{C}-6{ }^{\circ} \mathrm{C}(49 \%)$ (Fig. 3c). Therefore, it can be predicted that urban features, such as structural characteristics, materials, and building disposition type would change according to the housing complex newly built through new town development.

\section{Discussion}

This study is the first attempt to simulate and compare the pattern of UHI occurrence according to new town development using remote sensing and GIS technology. This discussion focuses on the principal two contributions of the proposed research in comparison with previous studies. Afterwards, the limitations are discussed. 

SUHI phenomenon depending on urban planning were visually and quantitatively shown for the study sites excluding external influences. To provide some examples, Tran et al. ${ }^{7}$ and Clinton\&Gong ${ }^{8}$ do comparative analysis of SUHI phenomenon between cities under different environment or urban situation. Tran et al. ${ }^{7}$ examine the spatial patterns of SUHIs for Asian mega cities based on the season and relationship with surface properties. Clinton\&Gong ${ }^{8}$ estimate the magnitude of SUHI for urban areas between latitudes 71 and -55 for the year 2010 using MODIS datasets. The results of these studies were successful in demonstrating the contribution of urbanization to the SUHI effect as well as investigating the differences in SUHI between urban and surrounding areas. However, applying these methods could not provide insight into the effect of different urban development types or urban planning on UHI phenomenon. In addition, in terms of comparing the UHI phenomenon between cities, there were some limitations which may lower the reliability of comparison. They all used satellite images constructed at different times and the magnitude of SUHI depends on whether a single image or composite over a period of time is used ${ }^{14}$. In comparison with these previous studies, this research provides a significant contribution by quantifying the influence of the urban planning involved in the UHI phenomenon based on a scientific approach in condition which external influences are controlled. The developed LULC maps showed significant changes in LULC before and after the development of new town from 1989 to 2018. The primary driver for the development of both the new towns was the transformation of agricultural areas to built-up areas. Moreover, the increase in built-up areas evidently intensified the SUHI phenomenon of an entire new town. However, the areas where the SUHI phenomenon additionally occurred or the SUHI intensity increased, were different according to the urban plan. These differences indicated the requirement and importance of urban planning to maintain a sustainable thermal environment, even with rapid LULC changes.

Our research also improves on the predictive models previously developed to study and predict usually LULC patterns. Unlike previous studies, Cellular Automata Markov Chain model was used for prediction of LULC changes and SUHI distribution changes accordingly in study areas. In the case of existing studies, the LULC change was simply predicted using the same model, but there was a limitation in not examining the urban climate change or other possible effects ${ }^{24,45-47}$. Saha et al. ${ }^{22}$ and Tariq $\& S h u^{57}$ tried to examine the LST change according to the LULC change. However, it did not predict the change of the LST distribution according to the predicted future LULC, and as in previous studies, indirect prediction was performed by simply constructing a regression equation using the spectral index. In addition, the LST value may vary depending on the radiative and 
aerodynamic properties of the satellite image and it is difficult to confirm the relative temperature increase in the built-up areas according to urban growth using LST distribution ${ }^{14}$. In this study, the predicted results based on variations between 2000 and 2018 also showed a possible future pattern of further urban expansion and similar changes in SUHI distribution and intensity in both new towns. characteristics in urban-level thermal environment changes was also suggested. According to Yahia et al., $(2018)^{60}$, closely speed high-rise buildings have a negative impact on ventilation and the average wind speed in the dense high-rise buildings area is less than half of that of the low-rise buildings area. However, when comparing the physiologically equivalent temperature, high-rise buildings is more comfortable, and the shade seems to be more important factor than wind speed. It means that decreasing solar radiation through shade will have a greater effect on decreasing sensible heat and thermal comfort near the surface than promoting the wind speed. When renovating old buildings in the future, three-dimensional design considering the effects of shadow and wind at the same time are required.

While the presented study provides useful method and information regarding the current and future status of the UHI phenomenon, it is still faced some limitations. This study does not consider additional parameters typically influencing the urban growth because of the specificity of the study area. As mentioned, new town is the planned city where the physical and legal aspects of the site were reviewed through feasibility analysis beforehand, the complication associated with urban expansion is relatively low for new town. However, the factors for urbanisation are related to the complexity of the terrain, degree of socio-economic development, urban regulations, etc ${ }^{24}$. Therefore, it is necessary to consider additional factors for urban expansion when applying this methodology to a region other than new town in the future. In addition, a model that explains the detailed behaviour of UHI using a combination of building renovation and structural characteristics is still necessary. Future research studies should attempt to obtain structural and temporal data over the same period of time and develop models able to explain the change of UHI based on structural characteristics changed by building renovation.

\section{Conclusions}

Although the research methods and measures face certain conceptual and practical challenges, this study suggested a proximate causal relationship between urban expansion and SUHI phenomenon change according to urban planning. It is easy to apply for practitioners and the necessary data for application are available without 
complex acquisition procedures or unopened access datasets. Therefore, the proposed novel method may be applied to both existing and newly built cities to predict future UHI distribution according to urban planning.

234 Furthermore, the findings and methods constructed through this research can be useful to policy makers, urban planners, researchers, and citizens to adopt sustainable thermal environment management practices including adaptation and mitigation strategies for the city.

\section{Methods}

Data acquisitions and pre-processing. Three Landsat images from May with an image quality of nine and cloud cover less than $2 \%$ were used to minimise the seasonal influence and cloud cover of each period: 1989 , 2000, and 2018. Two Landsat 5 thematic mapper (TM) and one Landsat 8 operational land imager/thermal infrared sensor (OLI/TIRS) images were obtained from the United States Geological Survey - Centre for Earth Resources Observation and Science (USGS-EROS) (http://earthexplorer.usgs.gov/). The images were used for LULC classification and SUHI calculation, and each period showed the change trends before and after the new town development. The remotely sensed data is an indirect measurement considering the intervening atmosphere and the surface radiative properties that influence the emission and reflection of radiation within the spectral wavelengths detected by the sensor ${ }^{9}$. Atmospheric correction using the dark object subtraction (DOS) method and radiometric correction for pre-processing using the semi-automatic classification (SCP) plugin in QGIS 3.14, were applied to the images. Atmospheric scattering and absorption caused the imaging system to record a non-zero digital number (DN) value for dark objects. The DOS method subtracted the constant nonzero DN value, DN haze, from the whole band, if some objects under complete shadow must have zero reflectance ${ }^{21}$.

Land use land cover classification. A supervised classification technique was used with the maximum likelihood classifier (MLC) algorithm to generate LULC maps for each year using the SCP plugin in QGIS 3.14. The MLC-based supervised classification approach was comprehensively used and considered as an established technique in many previous studies for urban LULC classification, where the spatial heterogeneity of pixels is similarly high ${ }^{22-24}$. The MLC algorithm is based on probability density distribution functions (likelihood), includes all training inputs for each land cover class, and has been proven to be an accurate and robust algorithm because it does not overestimate the class values during the computational process ${ }^{23-25}$. In addition, there are some advantages of the MLC algorithm, such as (1) auto-allocation of pixels to the unclassified regions based on the surrounding values ${ }^{25}$, and (2) the variance and covariance values of the class signatures are considered 
within the class distribution ${ }^{26}$. The Landsat images of 1989, 2000, and 2018 were classified into six major LULC classes, (i) built-up areas, covering the buildings and concrete areas; (ii) forest, covering coniferous and broadleaf forests; (iii) grass, covering natural and artificial grass; (iv) open spaces, covering natural and artificial bare areas; (v) agricultural areas, covering paddy field, dry field, etc.; and (vi) water bodies, covering ponds, lakes, and wetlands.

Assessment of classification accuracy is necessary to ensure that classification data can detect changes; this was conducted on the resulting classified imagery through an error matrix and kappa index that enables differentiation between ground-truth and predicted classification ${ }^{24,27}$. High-resolution Google Earth data and aerial photographs provided by the National Geographic Information Institute (NGII) of South Korea were used to establish ground-truth regions for the evaluation of classification accuracy (http://map.ngii.go.kr/). Highresolution data from Google Earth have been used as reference in many classification studies and national standardised land cover maps; NGII provides high-resolution aerial photographs captured since 1945, and can also be used for accuracy assessment ${ }^{22,24,28}$. The kappa coefficient was calculated using equation (1):

$$
k n p D a-\text { coefficient }=\frac{n \sum_{i=1}^{k} n i i-\sum_{i=1}^{k}\left(G_{i} C_{i}\right)}{n^{2}-\sum_{i=1}^{k}\left(G_{i} C_{i}\right)}
$$
where $i$ is the class number; $\mathrm{n}$ is the total number of points; $\mathrm{n}_{i i}$ is the number of pixels belonging to the actual data class $i$, which were classified as class $i ; \mathrm{C}_{i}$ is the total number of classified pixels belonging to class $i$; and $\mathrm{G}_{i}$ is the total number of actual data belonging to class $i$. Fifty sample points per class for each new town, except water class, were selected automatically by QGIS 3.14. A minimum of 50 samples must be collected for each land cover class in the error matrix to avoid the risk of a biased sample during accuracy assessment ${ }^{29}$.

LST estimation. LST estimation using ArcMap 10.5 includes transforming DNs to radiance $\left(\mathrm{L}_{\lambda}\right)$, measuring radiance brightness temperatures $\left(T_{B}\right)$, and adjusting emissivity to extract surface temperature from brightness maps $^{30}$. The LST values were obtained using thermal bands from Landsat TM (B6) and Landsat OLI/TIRS (B10) because of the USGS recommendation to avoid using TIRS band 11 because of its higher calibration uncertainty. zero $(K)$, and the signal received by the thermal sensors can be transformed to radiance $\left(L_{\lambda}\right)$ using equation (2): 


$$
L_{\lambda}=M_{L} \times Q_{C A L}+A_{L}
$$

286

287

288

where $\mathrm{L}_{\lambda}$ is the spectral radiance in $\mathrm{W} /\left(\mathrm{m}^{2 \times} \mathrm{sr} \times \mu \mathrm{m}\right) ; \mathrm{M}_{\mathrm{L}}$ is the radiance multiplicative scaling factor for the band; $\mathrm{A}_{\mathrm{L}}$ is the radiance additive scaling factor for the band; and $\mathrm{Q}_{\text {cal }}$ is the level 1 pixel value in $\mathrm{DN}$, whose values are obtained from the metadata of the Landsat images. After the DN value was converted to radiance, the radiance values were converted to $\mathrm{T}_{\mathrm{B}}$ using equation (3):

$$
T_{B}=K_{2} / \ln \left\lfloor\left(K_{1} / L_{\lambda}\right)+1\right]-273 \cdot 15
$$

where $T_{B}$ is the At-satellite brightness temperature and $K_{1}$ and $K_{2}$ represent the band-specific thermal conversion constants from the metadata. To obtain the temperature in Celsius, the radiant temperature is revised ${ }^{30}$. The final step in estimating the LST is to rectify the TB using land surface emissivity (LSE, $\varepsilon$ ) correction as shown in equation $(4)^{31}$ :

$$
L S T=\frac{T_{B}}{\left\lfloor 1+\left\lfloor\frac{\lambda \times T_{B}}{\rho}\right\rfloor \times \ln \epsilon\right\rfloor}
$$

where $\lambda$ is the wavelength of the emitted radiance $(=10.895 \mu \mathrm{m}) ; \rho=\mathrm{h} \times \mathrm{c} / \sigma\left(1.438 \times 10^{-2} \mathrm{~m} \mathrm{~K}\right)$, where $\mathrm{h}$ is Planck's constant $(6.626 \times 10-34 \mathrm{Js}), \mathrm{c}$ is the velocity of light $(2.998 \times 108 \mathrm{~m} / \mathrm{s})$, and $\sigma$ is the Boltzmann constant $(1.38 \times 10-23 \mathrm{~J} / \mathrm{K})$; and $\varepsilon$ is the emissivity ${ }^{30,32}$.

The obtained values of $T_{B}$ were referenced as a black body, whose properties are different from that of real objects on the Earth's surface and would also be different from real LST ${ }^{33}$. The LST values across a city can have a wide range, and it depends on LULC states constructed within the city. Furthermore, LSE, which is essential for estimating the LST, has strong land use/land cover dependence ${ }^{34,35}$.

The LSE value is calculated conditionally using equation (5), and the condition is represented by the formula for each emissivity value ${ }^{36,37}$ :

$$
\epsilon_{\lambda}=\epsilon_{\lambda} P_{\iota}+\epsilon_{\lambda s}\left(1-P_{\iota}\right)+C_{\lambda}
$$

where $\varepsilon_{\mathrm{v}}$ and $\varepsilon_{s}$ are the vegetation and soil emissivity, respectively and $\mathrm{C}_{\lambda}$ is the surface roughness $(\mathrm{C}=0$ for homogeneous and flat surfaces), with a constant value of $0.005^{38}$. When the normal difference vegetation index (NDVI) is less than $\mathrm{NDVI}_{\mathrm{S}}=0.2$, it is classified as bare soil and its emissivity value is acquired from the reflectance values in the red region $(\rho \mathrm{R})^{39}$. The NDVI values between 0.2 and 0.5 are considered as mixtures of 
soil and vegetation surfaces, and equation (5) is used for extracting their emissivity values. In the equation, $\varepsilon_{\lambda v}$ is the emissivity value of vegetation $(=0.9863 \mu \mathrm{m})$ and $\varepsilon_{\lambda \mathrm{s}}$ is emissivity value of soil $(=0.9668 \mu \mathrm{m})$ in this range ${ }^{40}$. When the NDVI value is larger than $\mathrm{NDVI}_{\mathrm{v}}=0.5$, it is considered as a vegetation surface and an emissivity value of 0.99 is assigned to $\mathrm{it}^{30}$. Visible red and near-infrared (NIR) bands were used for calculating NDVI using equation (6). In addition, NDVI values were used to evaluate the proportion of the vegetation $\left(\mathrm{P}_{\mathrm{v}}\right)$ related to emissivity $(\varepsilon)$ using equation $(7)^{41,42}$. A method for calculating $P_{v}$ using the NDVI values for vegetation soil, which can be applied in global conditions, was suggested in a previous study ${ }^{36}$.

$$
N D V I=\frac{N I R-R E D}{N I R+R E D}
$$

$$
P_{V}=\left\lfloor\frac{N D V I-N D V I_{S}}{N D V I_{V}-N D V I_{S}}\right\rfloor^{2}
$$

Urban expansion prediction. An integrated CA method combined with MCM was used for predicting urban expansion in 2028, 2038, and 2048 under the business-as-usual scenario of both new towns. The CA-MCM is a hybrid and robust algorithm in spatial and temporal dynamic modelling of LULC changes that includes the deterministic modelling framework, spatially explicit approach with stochastically based temporal framework ${ }^{43,44}$. In addition, CA-MCM analysis allows the user to add factors related to urban expansion into the model to improve accuracy, and it can be a support tool for land use planners and policy makers to establish future land use policies ${ }^{45}$. Furthermore, MCM is a tool used to evaluate adjustments in land use among cycles by a sequence of values that depend on the present state ${ }^{46}$. MCM defines the present temporal LULC change to predict future change, and equation (8) presents the calculation of land use change prediction ${ }^{47}$ :

$$
S(t, t+1)=P i j \times S(t)
$$

where $\mathrm{S}(\mathrm{t})$ is the system state at time $\mathrm{t}, \mathrm{S}(\mathrm{t}+1)$ is the system state at time $t+1$, and $\mathrm{P}_{\mathrm{ij}}$ is the transition probability matrix in a state, which is calculated using equation (9).

$$
P_{l j}=\left|\begin{array}{cccc}
P_{1,1} & P_{1,2} & \cdots & P_{1, N} \\
P_{2,1} & P_{2,2} & \cdots & P_{2, N} \\
\cdots & \cdots & \cdots & \cdots \\
P_{N, 1} & P_{N, 2} & \cdots & P_{N, N}
\end{array}\right|\left(0 \leq \mathrm{P}_{\mathrm{ij}} \leq 1\right)
$$


$\mathrm{P}$ is the Markov probability matrix, $\mathrm{P}_{i j}$ is the probability of converting from current state $i$ to another state $\mathrm{j}$ in prediction time, and $\mathrm{P}_{\mathrm{N}}$ is the state probability of any time. Low transition pixels have a low probability value near (0), and high-transition pixels have a high probability value near (1) ${ }^{47}$. The 2000 LULC map of the study area was used as the first base $\left(\mathrm{t}_{1}\right)$, and the 2018 LULC map was used as the other $\left(\mathrm{t}_{2}\right)$ to obtain the transition probability matrix in this study. However, MCM cannot completely predict the LULC change because it does not consider spatial knowledge distribution within each category, and transition probabilities are not constant among LULC states; therefore, it may suggest the appropriate degree of change but not the appropriate direction $^{48}$. according to the principle that each cell with its own characteristics can represent parcels of land and selfgrowth interactions as they are dynamic and can duplicate ${ }^{49}$. Land use changes for any location (cells) can be defined by the existing state and changes in the neighbouring cells, and the growth of objects is simulated in two directions ${ }^{45}$. Hence, CA-MCM, which incorporates the theories of Markov chain analysis and CA, has the advantages of forecasting in terms of utilising time series and space, and can achieve improved simulation for temporal and spatial patterns of land use changes ${ }^{50}$. Multi-criteria evaluation (MCE) was used to determine the LULC classes suitable for changing from the original state to another. MCE combines the factors driving urban growth and fuzzy systems analysis to construct transition suitability maps that show the probability that a pixel would change to another land cover class or remain unchanged ${ }^{51}$. The determinants and spatial expansion of urbanisation are related to the complexity of the terrain, degree of socio-economic development, urban regulations, etc ${ }^{24}$. However, in the case of new towns, as the physical and legal aspects of the site were reviewed through feasibility analysis, the complexity associated with urban expansion is relatively low.

In contrast, during urban planning in new town, physical planning and transportation infrastructure are more important for large-scale development to generate housing sites within a short period. Transportation infrastructure stimulates and guides urban growth by improving accessibility ${ }^{52-54}$. In addition, slope is an uncontrollable environmental factor that affects urban growth, because construction of buildings and development of cities on steep-slope terrain is difficult or sometimes impossible ${ }^{55}$. Hence, the distance to the main road, slope, and distance to the existing urban area were used to calculate transition suitability maps in this study. The maps of the road and digital elevation model (DEM) were obtained from National Spatial Data in Infrastructure Portal (NSDIP) (http://data.nsdi.go.kr/). Fuzzy membership functions were used to standardise suitability maps into $0-1$, where 0 represents unsuitable locations and 1 represents ideal locations for 
urbanisation. The area of each land class to be transformed into another LULC class was estimated based on the transition probabilities. These areas were separated by the number of iterations performed for CA to predict the areas to be converted per iteration. The future assignment of each cell to an LULC class was based on the suitability of the cell for that LULC class and the similarity of the cell with neighbouring cells of the same class. A contiguity filter of $5 \times 5$ pixels was used to define the effect of neighbouring pixels on the central pixel.

Mapping and prediction of the SUHI distribution. The UHI effect occurs due to the anthropogenic modification of natural landscapes in the city boundary layer, and as the urban area increases, the UHI intensity also increases ${ }^{14}$. In addition, LST and SUHI effects are particularly related to the surrounding sub-urban environment ${ }^{8,14}$. To analyse this trend, the SUHI intensity of each new town was defined as the difference between the temperatures of an urban area and its surrounding areas (LULC, excluding built-up area) within the boundary ${ }^{4,13,15}$. Thus, the SUHI intensity distribution maps for each new town and each period were constructed using two steps. (1) The SUHI intensity variation was calculated using equation (10):

$$
\text { SUHI intensity distribution }=\mathrm{T}_{\mathrm{s}}-(\mathrm{T} \text { mean }+0.5 \times \delta) \text { surrounding area }
$$

where $\mathrm{T}_{\mathrm{s}}$ is the LST $\left({ }^{\circ} \mathrm{C}\right)$ distribution of new town, and $\mathrm{T}_{\text {mean }}$ and $\delta$ are the mean and standard deviation of LST in non-urban areas of new town. By subtracting the average temperature of non-urban areas from the temperature of the entire city, it may be verified that the actual SUHI effect was due to urban expansion, rather than the temporary LST value. In addition, the water bodies were excluded while calculating the SUHI intensity because it can irregularly influence the surface temperature (Lee et al, 2020). (2) The SUHI intensity variation was classified into six appropriate ranges: (i) value $\leq 0{ }^{\circ} \mathrm{C}$, (ii) $0{ }^{\circ} \mathrm{C}<$ value $\leq 2{ }^{\circ} \mathrm{C}$, (iii) $2{ }^{\circ} \mathrm{C}<$ value $\leq 4{ }^{\circ} \mathrm{C}$, (iv) $4{ }^{\circ} \mathrm{C}<$ value $\leq 6{ }^{\circ} \mathrm{C}$, (v) $6{ }^{\circ} \mathrm{C}<$ value $\leq 8{ }^{\circ} \mathrm{C}$, (vi) $8{ }^{\circ} \mathrm{C}<$ value. Thus, the difference in distribution and intensity of the SUHI phenomenon can be compared according to the change in LULC for each new town at each time period. In addition, classes are divided into value ranges, to facilitate future SUHI intensity distribution prediction using CA-Markov analysis. The indices, which were positively and negatively correlated with LST, were used to develop transition suitability maps for predicting the SUHI distribution. The normalised difference built-up index (NDBI) was used as the index that highly correlated with $\mathrm{LST}^{56}$. NDBI is the most widely accepted tool for the identification of built-up areas and has shown a high surface temperature correlation in previous studies ${ }^{13,22,57}$. The NDBI value was calculated using equation (11): 


$$
N D B I=\frac{S W I R-N I R}{S W I R+N I R}
$$

383

384

385

386

387

388

389

390

391

392

393

394

395

396

397

398

399

400

401

402

403

404

405

406

407

408

409

Built-up areas are sensitive under the 1.55-1.75 wavelength range in the short-wave infrared (SWIR) band; however, they are less sensitive under the $0.79-0.90$ wavelength range in the NIR band ${ }^{58}$. The NDBI values range from -1 to +1 , and values near +1 generally represent highly dense built-up areas. Furthermore, NDVI was used as the index that weakly correlated with LST. NDVI is the most common index for vegetation extraction and has shown a strong negative correlation with LST in previous studies ${ }^{32,57,59}$. Fuzzy membership functions were also used to standardise the factor maps to $0-1$, where 0 represents a low SUHI potential and 1 represents a high SUHI potential.

\section{Data availability}

Satellite images from 1989 to 2018 used in this study are freely available at httl://earthexplorer.usgs.gov/. Other datasets are available upon request from K. Lee (leedake@korea.ac.kr).

\section{References}

1. United Nations. The World's cities in 2018. Department of Economic and Social Affairs, Population Division, World Urbanization Prospects 1-34 (2018).

2. Liping, C., Yujun, S., \& Saeed, S. Monitoring and predicting land use and land cover changes using remote s ensing and GIS techniques—A case study of a hilly area, Jiangle, China. PloS One 13(7), e0200493 (2018).

3. Eliasson, I. The use of climate knowledge in urban planning. Landsc. Urban Plan. 48(1-2), 31-44 (2000).

4. Lee, K., Kim, Y., Sung, H. C., Ryu, J., \& Jeon, S. W. Trend analysis of urban heat island intensity according to urban area change in Asian mega cities. Sustain. 12(1), 112 (2020).

5. Grimmond, S. U. Urbanization and global environmental change: local effects of urban warming. Geogr. J. 173( 1), $83-88$ (2007).

6. Santamouris, M. Using cool pavements as a mitigation strategy to fight urban heat island-A review of the act ual developments. Renew. Sustain. Energy Rev. 26, 224-240 (2013).

7. Tran, H., Uchihama, D., Ochi, S., \& Yasuoka, Y. Assessment with satellite data of the urban heat island effec ts in Asian mega cities. Int. J. Appl. Earth Obs. Geoinform. 8(1), 34-48 (2006).

8. Clinton, N., \& Gong, P. MODIS detected surface urban heat islands and sinks: Global locations and controls 
9. Voogt, J. A., \& Oke, T. R. Thermal remote sensing of urban climates. Remote Sens. Environ. 86(3), 370-384 ( 2003).

10. Khammar, G. Analysis the Environmental Impacts of Pardis New Town By TOPSIS Model. Int. J. Manag. Sci. Bus. Res. 2(7), 134-141 (2013).

11. Wakeman, R.. Practicing Utopia: An Intellectual History of the New Town Movement Ch. 2 (University of Chi cago Press, 2016).

12. Qaid, A., Lamit, H. B., Ossen, D. R., \& Shahminan, R. N. R. Urban heat island and thermal comfort conditio ns at micro-climate scale in a tropical planned city. Energy Build. 133, 577-595 (2016).

13. Guha, S., Govil, H., Dey, A., \& Gill, N. Analytical study of land surface temperature with NDVI and NDBI using Landsat 8 OLI and TIRS data in Florence and Naples city, Italy. Eur. J. Remote Sens. 51(1), 667-678 (2 018).

14. Oke, T., et al. Urban Climates Ch. 7 (Cambridge University Press, 2017)

15. Zhou, B., Rybski, D., \& Kropp, J. P. On the statistics of urban heat island intensity. Geophys. Res. Lett. 40(20) , 5486-5491 (2013).

16. Raymond, W. H., Rabin, R. M., \& Wade, G. S. Evidence of an agricultural heat island in the lower Mississip pi River floodplain. Bull. Am. Meteorol. Soc. 75(6), 1019-1026 (1994).

17. Huovila, P. Buildings and Climate Change: Status, Challenges, and Opportunities Ch. 1 (UNEP/Earthprint. 2007 ) .

18. Li, Y., Schubert, S., Kropp, J. P., \& Rybski, D. On the influence of density and morphology on the Urban H eat Island intensity. Nature Commun. 11(1), 1-9 (2020).

19. Häkkinen, T., et al. Methods and Concepts for Sustainable Renovation of Building Ch. 4 (VTT Technical Resea rch Centre of Finland: Espoo, Finland, 2012).

20. Yeh, S. W., et al. The record-breaking heat wave in 2016 over South Korea and its physical mechanism. Mon. Weather Rev. 146(5), 1463-1474 (2018).

21. Nazeer, M., Nichol, J. E., \& Yung, Y. K. Evaluation of atmospheric correction models and Landsat surface ref lectance product in an urban coastal environment. Int. J. Remote Sens. 35(16), 6271-6291 (2014).

22. Saha, P., Bandopadhyay, S., Kumar, C., \& Mitra, C. Multi-approach synergic investigation between land surfac e temperature and land-use land-cover. J. Earth Syst. Sci. 129(1), 1-21 (2020).

23. Sun, J., Yang, J., Zhang, C., Yun, W., \& Qu, J. Automatic remotely sensed image classification in a grid envi ronment based on the maximum likelihood method. Math. Computer Model. 58(3-4), 573-581 (2013).

24. Wang, S. W., Munkhnasan, L., \& Lee, W. K. Land use and land cover change detection and prediction in Bh utan's high altitude city of Thimphu, using cellular automata and Markov chain. Environmental Challenges. 2, 1 
00017 (2020).

25. Al-Ahmadi, F. S., \& Hames, A. S. Comparison of four classification methods to extract land use and land cov er from raw satellite images for some remote arid areas, Kingdom of Saudi Arabia. Earth 20(1), 167-191 (2009 ) .

26. Erbek, F. S., Özkan, C., \& Taberner, M. Comparison of maximum likelihood classification method with superv ised artificial neural network algorithms for land use activities. Int. J. Remote Sens. 25(9), 1733-1748 (2004).

27. Yuan, D. A simulation comparison of three marginal area estimators for image classification. Photogramm. Eng. Remote Sens. 63(4), 385-391 (1997).

28. Lee, K., et al. The Integration of Remote Sensing and Field Surveys to Detect Ecologically Damaged Areas fo r Restoration in South Korea. Remote Sens. 12(22), 3687 (2020).

29. Congalton, R. G. A review of assessing the accuracy of classifications of remotely sensed data. Remote Sens. E nviron. 37(1), 35-46 (1991).

30. Avdan, U., \& Jovanovska, G. Algorithm for automated mapping of land surface temperature using LANDSAT 8 satellite data. J. Sens. 2016, 1-8 (2016).

31. Artis, D. A., \& Carnahan, W. H. Survey of emissivity variability in thermography of urban areas. Remote Sens. Environ. 12(4), 313-329 (1982).

32. Weng, Q., Lu, D., \& Schubring, J. Estimation of land surface temperature-vegetation abundance relationship fo r urban heat island studies. Remote Sens. Environ. 89(4), 467-483 (2004).

33. Shen, H., Huang, L., Zhang, L., Wu, P., \& Zeng, C. Long-term and fine-scale satellite monitoring of the urba $\mathrm{n}$ heat island effect by the fusion of multi-temporal and multi-sensor remote sensed data: A 26-year case study of the city of Wuhan in China. Remote Sens. Environ. 172, 109-125 (2016).

34. Mallick, J., Singh, C. K., Shashtri, S., Rahman, A., \& Mukherjee, S. Land surface emissivity retrieval based o n moisture index from LANDSAT TM satellite data over heterogeneous surfaces of Delhi city. Int. J. Appl. Ea rth Obs. Geoinform. 19, 348-358 (2012).

35. Radhi, H., Fikry, F., \& Sharples, S. Impacts of urbanisation on the thermal behaviour of new built up environ ments: A scoping study of the urban heat island in Bahrain. Landsc. Urban Plan. 113, 47-61 (2013).

36. Sobrino, J. A., Jiménez-Muñoz, J. C., \& Paolini, L. Land surface temperature retrieval from LANDSAT TM 5 . Remote Sens. Environ. 90(4), 434-440 (2004).

37. Wang, F., et al. An improved mono-window algorithm for land surface temperature retrieval from Landsat 8 th ermal infrared sensor data. Remote Sens. 7(4), 4268-4289 (2015).

38. Sobrino, J. A., \& Raissouni, N. Toward remote sensing methods for land cover dynamic monitoring: Applicatio n to Morocco. Int. J. Remote Sens. 21(2), 353-366 (2000). 

), 294 (2020).

40. Yu, X., Guo, X., \& Wu, Z. Land surface temperature retrieval from Landsat 8 TIRS - Comparison between rad iative transfer equation-based method, split window algorithm and single channel method. Remote Sens. 6(10), 9 829-9852 (2014).

41. Carlson, T. N., \& Ripley, D. A. On the relation between NDVI, fractional vegetation cover, and leaf area inde x. Remote Sens. Environ. 62(3), 241-252 (1997).

42. Tucker, C. J. Red and photographic infrared linear combinations for monitoring vegetation. Remote Sens. Enviro n. 8(2), 127-150 (1979).

43. Kamusoko, C., Aniya, M., Adi, B., \& Manjoro, M. Rural sustainability under threat in Zimbabwe-simulation o f future land use/cover changes in the Bindura district based on the Markov-cellular automata model. Appl. Geo gr. 29(3), 435-447 (2009).

44. Keshtkar, H., \& Voigt, W. A spatiotemporal analysis of landscape change using an integrated Markov chain an d cellular automata models. Model. Earth Syst. Environ. 2(1), 10 (2016).

45. Hamad, R., Balzter, H., \& Kolo, K. Predicting land use/land cover changes using a CA-Markov model under $\mathrm{t}$ wo different scenarios. Sustain. 10(10), 3421 (2018).

46. Aaviksoo, K. Simulating vegetation dynamics and land use in a mire landscape using a Markov model. Landsc. Urban Plan. 31(1-3), 129-142 (1995).

47. Kumar, S., Radhakrishnan, N., \& Mathew, S. Land use change modelling using a Markov model and remote s ensing. Geomat. Nat. Hazards Risk 5(2), 145-156 (2014).

48. Boerner, R. E., et al. Markov models of inertia and dynamism on two contiguous Ohio landscapes. Geogr. Ana l. 28(1), 56-66 (1996).

49. Brown, D. G., Walker, R., Manson, S., \& Seto, K. Modeling land use and land cover change. In Land change science (pp. 395-409). (Springer, Dordrecht, 2012).

50. Sang, L., Zhang, C., Yang, J., Zhu, D., \& Yun, W. Simulation of land use spatial pattern of towns and villag es based on CA-Markov model. Math. Computer Model. 54(3-4), 938-943 (2011).

51. Myint, S. W., \& Wang, L. Multicriteria decision approach for land use land cover change using Markov chain analysis and a cellular automata approach. Can. J. Remote Sens. 32(6), 390-404 (2006).

504 52. Anas, A., Arnott, R., \& Small, K. A. Urban spatial structure. J. Econ. Lit. 36(3), 1426-1464 (1998).

53. Hu, Z., \& Lo, C. P. Modeling urban growth in Atlanta using logistic regression. Computers Environ. Urban Sy st. 31(6), 667-688 (2007).

54. Kasraian, D., Maat, K., \& van Wee, B. The impact of urban proximity, transport accessibility and policy on u rban growth: A longitudinal analysis over five decades. Environ. Plan. B 46(6), 1000-1017 (2019). 
509 55. Kechebour, B. E. Relation between stability of slope and the urban density: case study. Proced. Eng. 114, 824831 (2015).

511 56. Zha, Y., Gao, J., \& Ni, S. Use of normalized difference built-up index in automatically mapping urban areas $\mathrm{f}$ rom TM imagery. Int. J. Remote Sens. 24(3), 583-594 (2003).

513 57. Tariq, A., \& Shu, H. CA-Markov Chain Analysis of Seasonal Land Surface Temperature and Land Use Land

514 Cover Change Using Optical Multi-Temporal Satellite Data of Faisalabad, Pakistan. Remote Sens. 12(20), 3402 ( 515 2020).

516 58. Bhatti, S. S., \& Tripathi, N. K. Built-up area extraction using Landsat 8 OLI imagery. GIScience Remote Sens $517 \quad$ 51(4), 445-467 (2014).

518 59. Sun, H., Chen, Y., \& Zhan, W. Comparing surface-and canopy-layer urban heat islands over Beijing using MO DIS data. Int. J. Remote Sens. 36(21), 5448-5465 (2015).

520 60. Yahia, M. W., Johansson, E., Thorsson, S., Lindberg, F., \& Rasmussen, M. I. Effect of urban design on micro 521 climate and thermal comfort outdoors in warm-humid Dar es Salaam, Tanzania. International journal of biomete orology, 62(3), 373-385 (2018). 


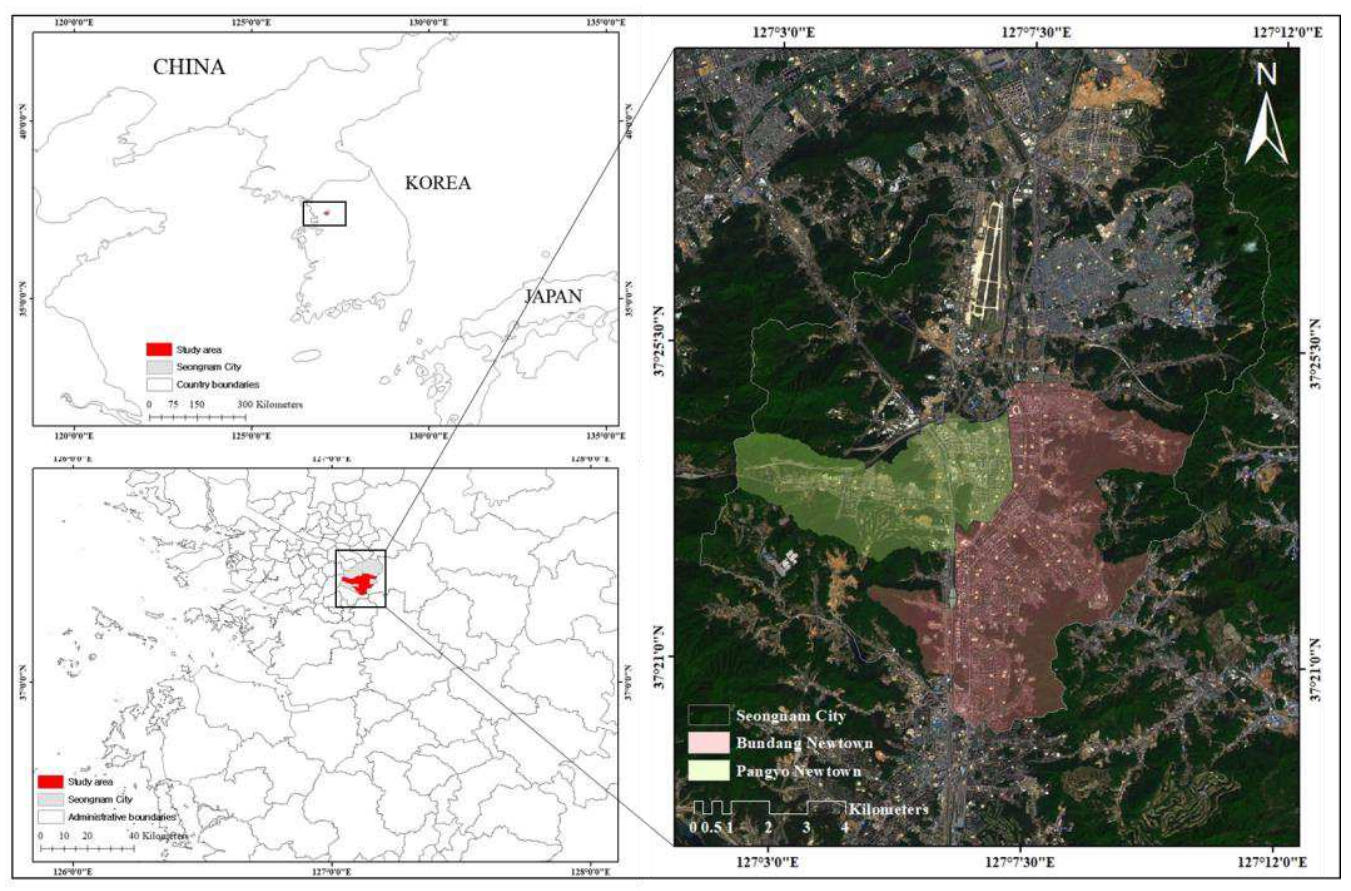

527 Fig. 1 Map of study area. a. Geographical location of the two new towns. b. Enlarged image showing the new towns. c. Landsat OLI image acquired on May 09, 2018. 


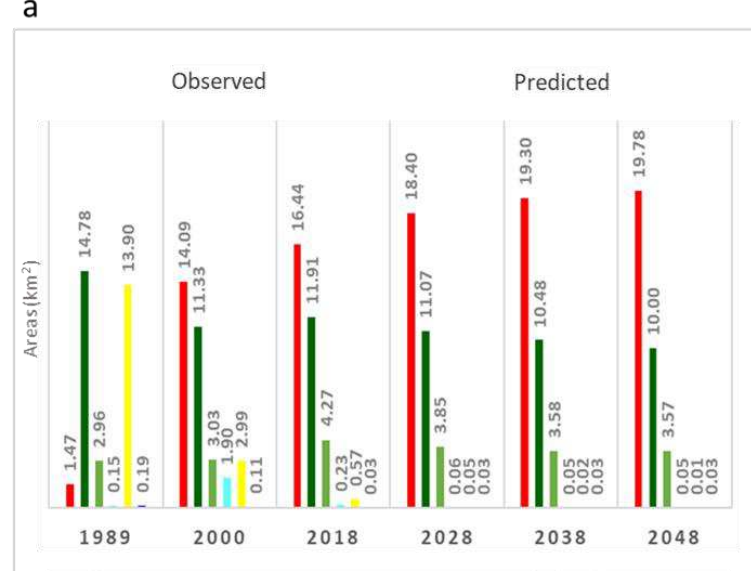

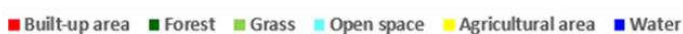
c
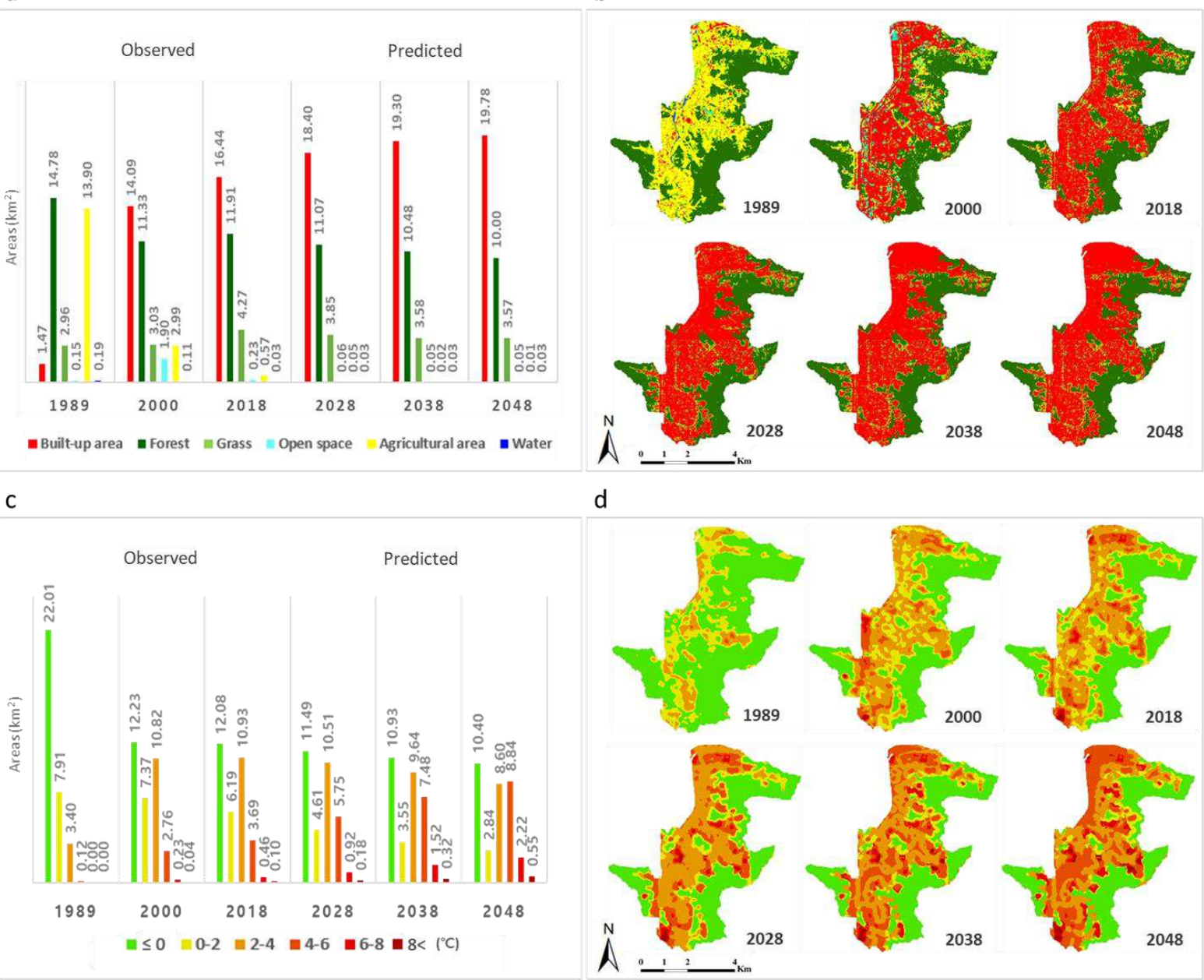

d

Fig. 2 SUHI distribution according to LULC changes from 1989 to 2048 in Bundang new town. a. Areas of

531 LULC in Bundang new town from 1989 to 2048. b. LULC maps of Bundang new town from 1989 to 2048. c.

532 Areas of SUHI distribution in Bundang new town from 1989 to 2048. d. SUHI distribution maps of Bundang new town from 1989 to 2048 . 


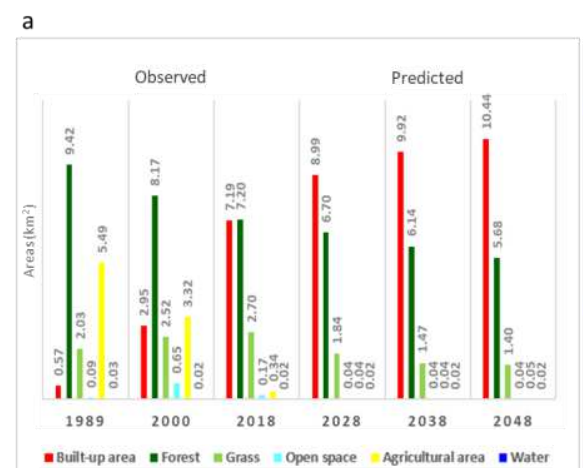

b

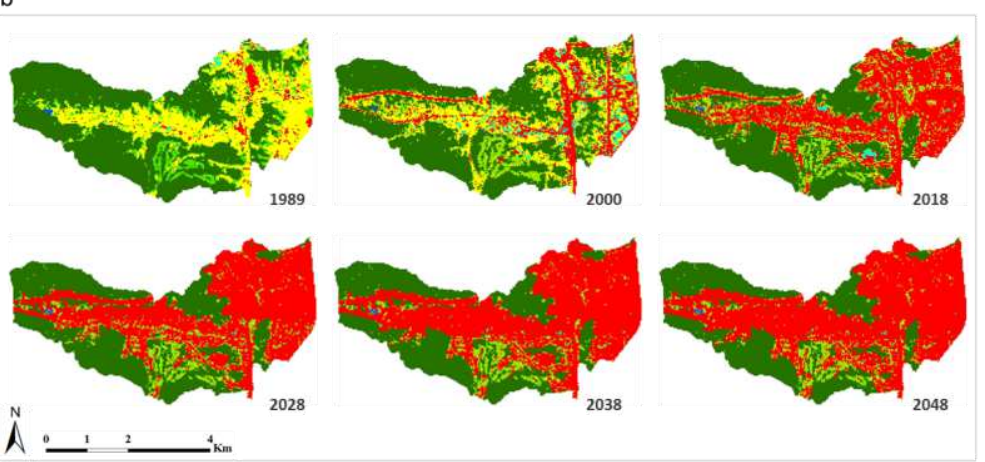

d
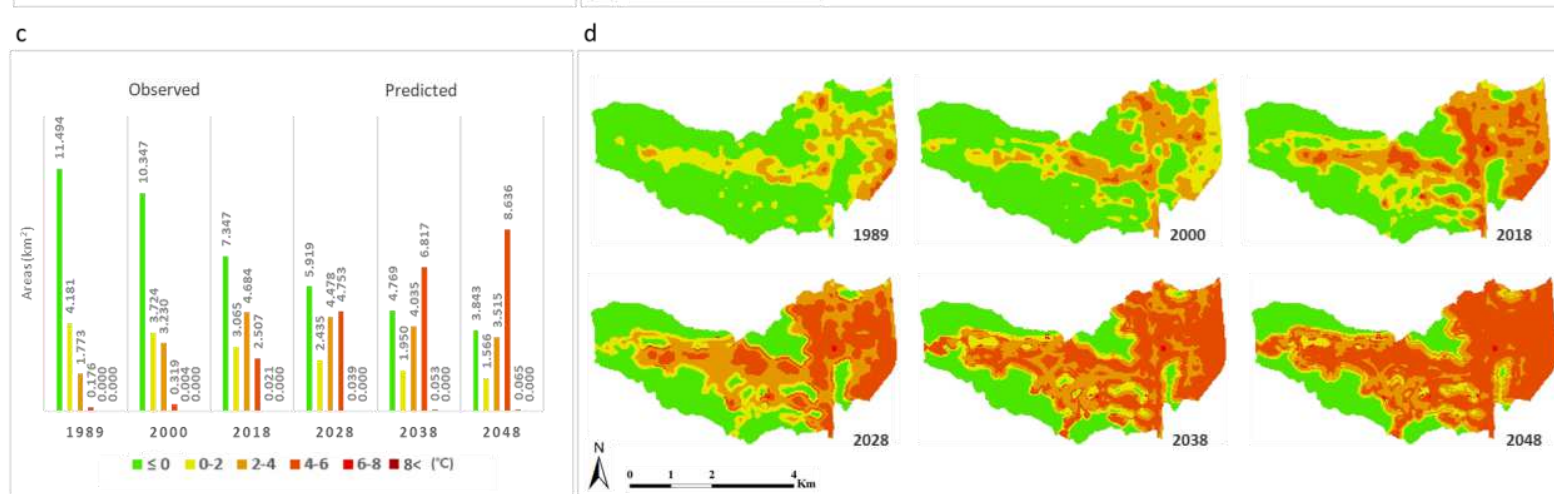

535 Fig. 3 SUHI distribution according to LULC changes from 1989 to 2048 in Pangyo new town. a. Areas of

536 LULC in Pangyo new town from 1989 to 2048. b. LULC maps of Pangyo new town from 1989 to 2048. c. Areas

537 of SUHI distribution in Pangyo new town from 1989 to 2048. d. SUHI distribution maps of Pangyo new town from 1989 to 2048. 
Table 1. Development plan features for each new town

\begin{tabular}{lll}
\hline Division (unit) & Bundang new town & Pangyo new town \\
\hline Generation of New town & $1^{\text {st }}$ generation & $2^{\text {nd }}$ generation \\
Development period & $1989-1996$ & $2003-2017$ \\
Whole area $\left(\mathrm{km}^{2}\right)$ & 33.45 & 17.62 \\
Development plan area $\left(\mathrm{km}^{2}\right)$ & 19.64 & 8.9 \\
Number of household (thousands) & 97.6 & 29.3 \\
Population density (number/ha) & 199 & 98 \\
Average greenspace ratio $(\%)$ & $12-25$ & $25-35$ \\
Average floor space ratio $(\%)$ & 184 & 161 \\
Transportation infrastructure & Vehicle-oriented & Public transportation-oriented \\
\hline
\end{tabular}

\section{$541 \quad$ Acknowledgements}

542 This work was conducted with the support of the Korea Environment Industry \& Technology Institute (KEITI)

543 through its Urban Ecological Health Promotion Technology Development Project, and funded by the Korea

544 Ministry of Environment (MOE) (2020002770003).

\section{Author contributions}

546 K. Lee, S.H. Kim, and S.W. Jeon: research design; H.C. Sung and Y. Kim: data collection; K. Lee, Y. Kim, and

547 H.C. Sung: empirical analysis; K. Lee and S.H. Kim: manuscript draft; and all authors: result interpretation and

548 writing the paper.

\section{Competing interests}

550 The authors declare no competing interests. 


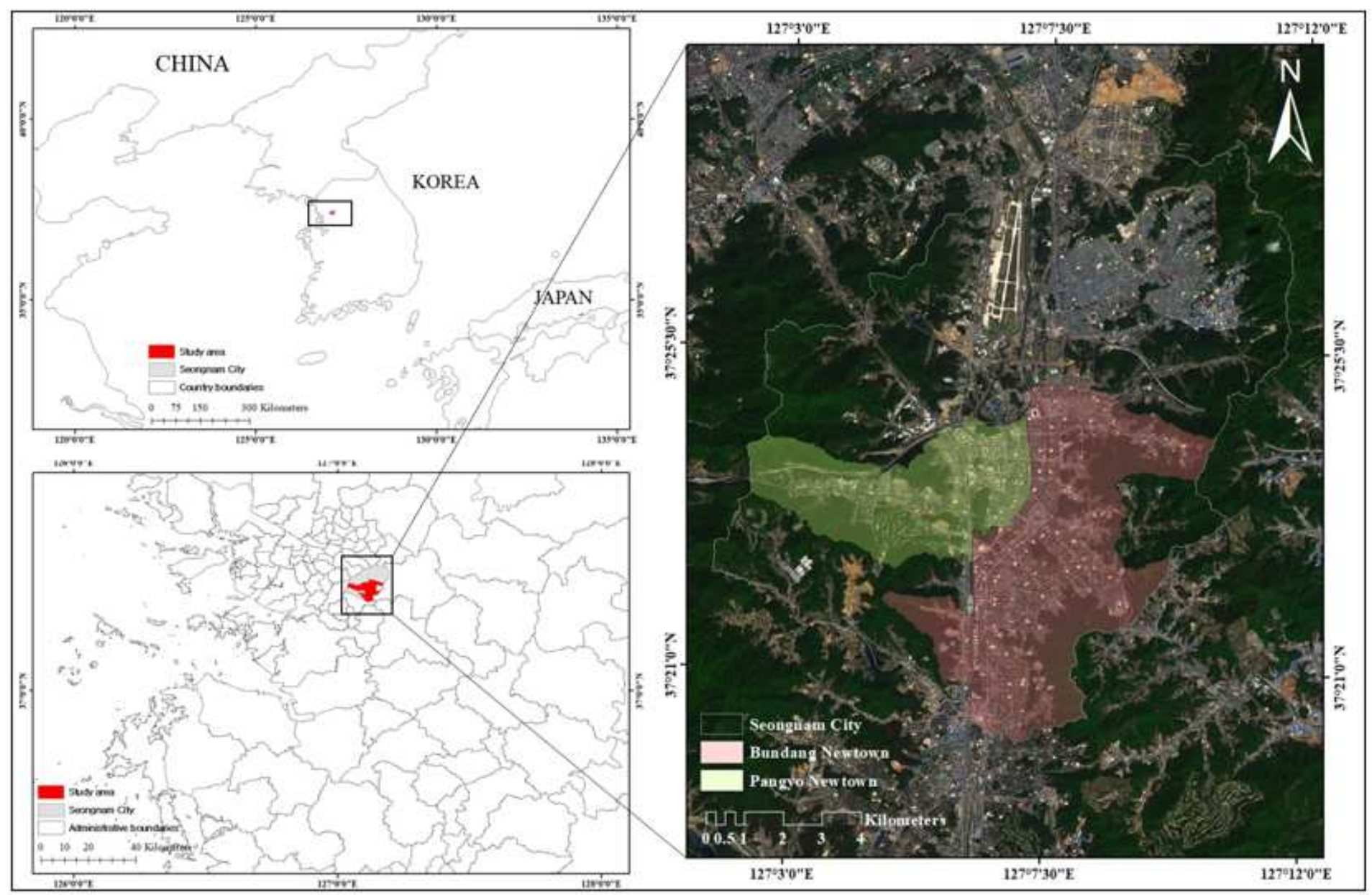

\section{Figure 1}

Map of study area. a. Geographical location of the two new towns. b. Enlarged image showing the new towns. c. Landsat OLI image acquired on May 09, 2018. Note: The designations employed and the presentation of the material on this map do not imply the expression of any opinion whatsoever on the part of Research Square concerning the legal status of any country, territory, city or area or of its authorities, or concerning the delimitation of its frontiers or boundaries. This map has been provided by the authors. 



C

d

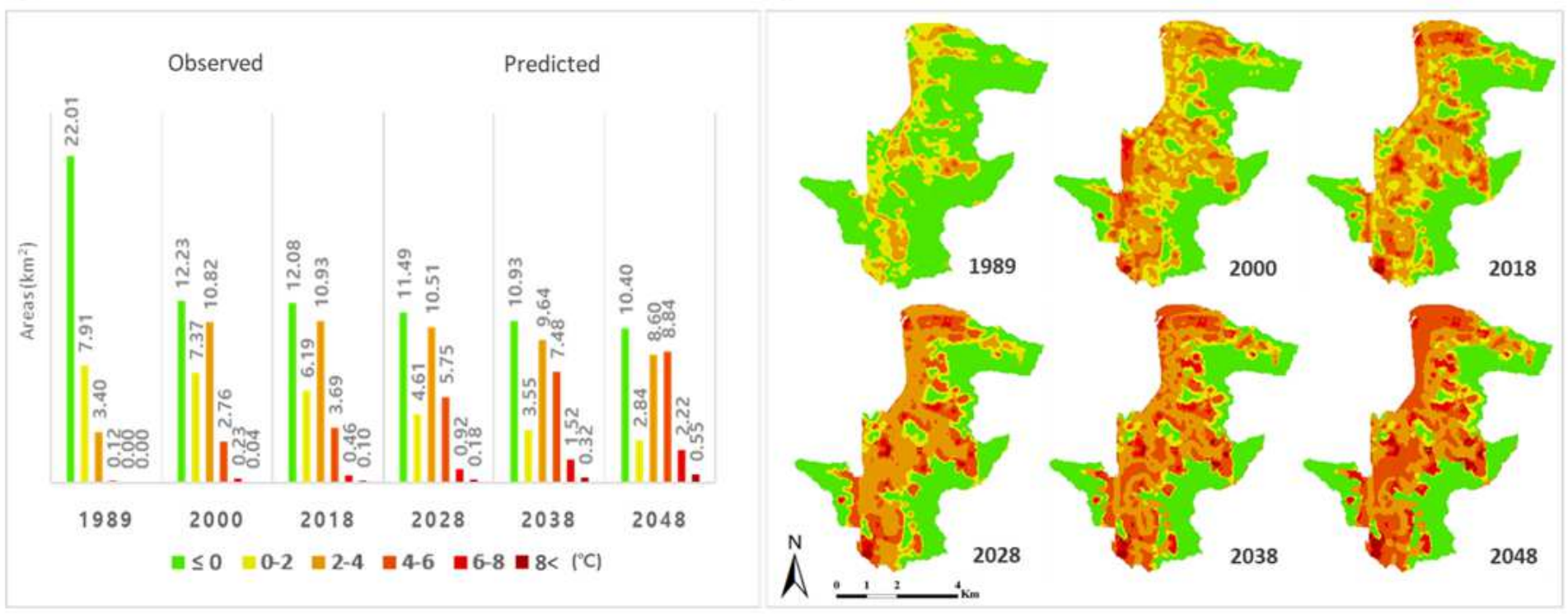

\section{Figure 2}

SUHI distribution according to LULC changes from 1989 to 2048 in Bundang new town. a. Areas of LULC in Bundang new town from 1989 to 2048. b. LULC maps of Bundang new town from 1989 to 2048. c. Areas of SUHI distribution in Bundang new town from 1989 to 2048. d. SUHI distribution maps of Bundang new town from 1989 to 2048. Note: The designations employed and the presentation of the material on this map do not imply the expression of any opinion whatsoever on the part of Research Square concerning the legal status of any country, territory, city or area or of its authorities, or concerning the delimitation of its frontiers or boundaries. This map has been provided by the authors. 
a

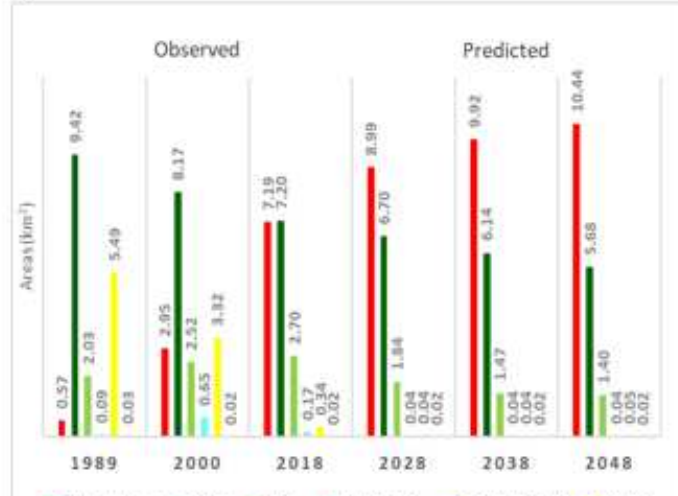

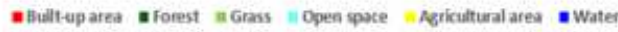

c

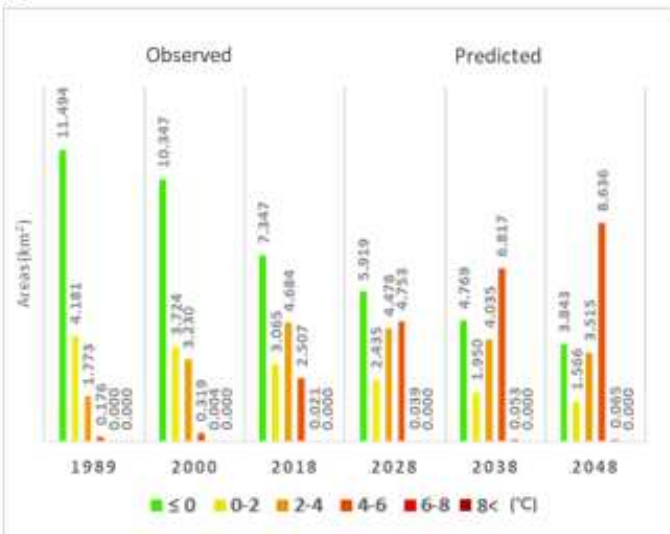

b
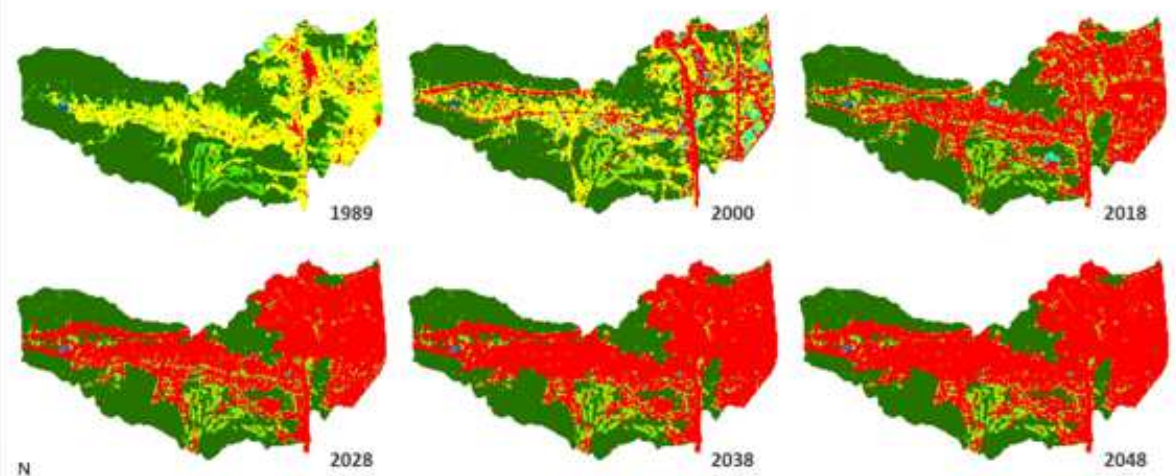

$\AA^{\mathrm{N}}+{ }^{2}{ }^{\mathrm{Km}}$

d


Figure 3

SUHI distribution according to LULC changes from 1989 to 2048 in Pangyo new town. a. Areas of LULC in Pangyo new town from 1989 to 2048. b. LULC maps of Pangyo new town from 1989 to 2048. c. Areas of SUHI distribution in Pangyo new town from 1989 to 2048. d. SUHI distribution maps of Pangyo new town from 1989 to 2048. Note: The designations employed and the presentation of the material on this map do not imply the expression of any opinion whatsoever on the part of Research Square concerning the legal status of any country, territory, city or area or of its authorities, or concerning the delimitation of its frontiers or boundaries. This map has been provided by the authors. 